\title{
Naudan maidontuotantogeenien alkiodiagnostiikka
}

Sirja Viitala, Jaana Peippo, Mervi Räty, Jouni Virta, Tuula-Marjatta Hamama, Juha-Pekka Seppänen, Johanna Jokinen, Asko Mäki-Tanila ja Johanna Vilkki MTT, Maa-ja elintarviketalouden tutkimuskeskus, Kotieläintuotannon tutkimus, 31600 Jokioinen. etunimi.sukunimi@mtt.fi

\section{Johdanto}

MTT:ssä on kartoitettu kotieläinten jalostuksellisesti tärkeisiin ominaisuuksiin vaikuttavia kromosomialueita vuodesta 1993. Naudan geenikartoituksen ensimmäinen vaihe saatiin päätökseen vuonna 2000. Naudan perimästä on tunnistettu useita maidon tuotantoon, terveyteen ja hedelmällisyyteen vaikuttavia alueita. Muita kotieläimistä kartoitettuja ominaisuuksia ovat sian siittiöiden liikkumattomuus-syndrooma sekä useat kanan munien tuotantoon ja laatuun liittyvät ominaisuudet. Alueita hienokartoitetaan vaikutuksen taustalla olevien geenien tunnistamiseksi ensimmäiset naudan maidontuotantoon vaikuttavat geenimuutokset on jo löydetty.

Kartoitettuja geenejä voidaan hyödyntää tehostamaan jalostusta markkeriavusteisella valinnalla. Yhdestä eläimestä voidaan tuottaa paljon perimältään valikoituja jälkeläisiä yhdistämällä alkiotuotanto ja alkiodiagnostiikka. Alkiot huuhdellaan hormonikäsitellyistä (superovuloiduista) luovuttajista viikon kuluttua siemennyksestä. Hyvälaatuisista alkioista leikataan näytepala sukupuolen määrittämistä ja valittaviin ominaisuuksiin kytkeytyneiden geenimerkkien analysointia varten. Analyysituloksen perusteella haluttuja ominaisuuksia perineet alkiot siirretään vastaanottajaan. Tulevaisuuden jalostusta silmälläpitäen alkiodiagnostiikkaa on kehitetty ja testattu MTT:ssä ASMO-alkionsiirtoydinkarjassa.

\section{Naudan geenikartoitus}

Naudan geenikartoituksen ensimmäinen vaihe saatiin päätökseen vuonna 2000 (Viitala ym, 2003; Schulman ym, 2003). Naudan koko perimästä rakennettiin molekyyligeneettisten DNA-merkkien avulla kartta. Karttaa hyödyntämällä naudan perimästä on tunnistettu useita maidontuotantoon, terveyteen ja hedelmällisyyteen vaikuttavaa kromosomialuetta (QTL, quantitative trait loci).

Perinteisesti geenikartoitus perustuu risteytyksiin. Naudan geenikartoituksessa on kustannustehokkaampaa käyttää olemassa olevaa jalostuspopulaatiota. Mallit jotka hyödyntävät olemassa olevia populaatioita, soveltuvat risteytyksiä paremmin suurille ja hitaasti lisääntyville eläimille. Pojantytärmallin mukaisessa tutkimusaineistossa on jalostusarvosteltuja keinosiemennyssonneja - isiä ja niiden poikia. Haluttujen kromosomien (tässä tapauksessa koko kromosomiston) DNA-karttamerkkien periytymistä seurataan isiltä pojille. Tietoa siitä mitä alueita poika on isänsä kromosomipareista perinyt käytetään etsittäessä yhteyttä kromosomialueiden ja tutkittavien ominaisuuksien väliltä. Kussakin tarkasteltavassa kromosomikohdassa jokaisen isän pojat voidaan luokitella kahteen ryhmään sen mukaan mitä ne ovat isältään perineet. Näiden kahden ryhmän välisiä fenotyyppisiä eroja tarkastellaan tilastollisesti. Analyysissä käytettävät poikien fenotyypit ovat niiden tyttärien tietojen perusteella laskettuja jalostusarvoja.

Markkereita on $10-20 \mathrm{cM}: n$ välein. Tällaisessa kartoituksessa käytetyillä menetelmillä ei saavuteta riittävää tarkkuutta, jotta tuloksia voitaisiin tehokkaasti hyödyntää jalostuksen apuvälineenä. Tarkkuus ei myöskään riitä yksittäisten geenien tunnistamiseksi. Paras karttamerkki markkeriavusteiseen valintaan (MAS; marker assisted selection) olisikin itse vaikuttavasta geenistä tunnistettu muutos. Tästä syystä markkereita haetaan ja paikannetaan edelleen karttojen erotuskyvyn parantamiseksi.

Hienokartoituksen tavoitteena on rajata ominaisuuksien taustalla vaikuttavien geenien sijainti mahdollisimman lyhyelle kromosomialueelle. Kartoitus edellyttää lisäaineiston keräämistä ja markkerikartan huomattavaa tihentämistä. Hienokartoituksessa käytetään uusimpia genomiikan ja tilastotieteen menetelmiä. Menetelmien vaatiman suuren aineiston ja työmäärän vuoksi tutkimukset toteutetaan kansainvälisenä yhteistyönä kuten EU-projekti EURIBDIS (naudan maidontuotantoon vaikuttavien geenialueiden hienokartoitus) vuosina 1998-2001. MTT koordinoi lokakuussa 2002 aloitettua EU-projektia MASTITIS RESISTANCE, jonka tavoitteena on tuottaa uusia valintatyökaluja eurooppalaisen lypsykarjan utaretulehdusalttiuden vähentämiseksi. 


\section{Geenikartoitustuloksia}

Kartoituksen ensimmäisessä vaiheessa käytiin läpi naudan koko perimä. Kartoituksessa käytettiin 24 ayrshiresonnin pojista koostuvaa noin 900 sonnin aineistoa. Jokaisesta kromosomista analysoitiin tasaisin välimatkoin sijaitsevia DNA-karttamerkkejä. Sen jälkeen selvitettiin tilastollisin menetelmin eri ominaisuuksiin: 5 maidontuotanto-, 4 terveys- ja 3 hedelmällisyysominaisuuteen liittyvän vaihtelun assosioituminen karttamerkkien vaihteluun. Tutkimuksessa löytyi kymmeniä QTL-alueita, jotka vaikuttavat yhteen tai useampaan ominaisuuteen (kuva1).
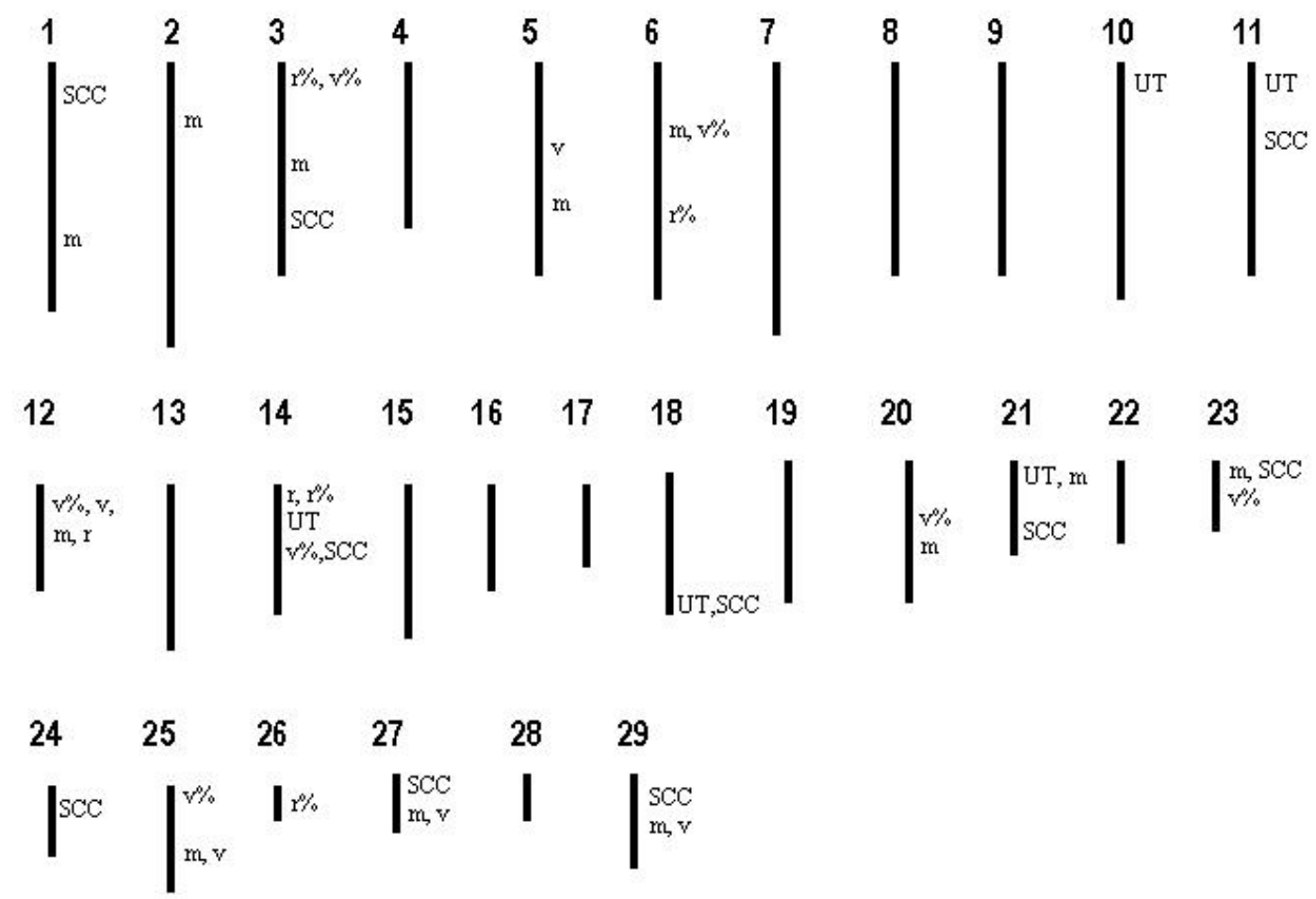

Kuva 1. Ayrshiren perimän (29 kromosomiparia) kartoituksessa löytyneitä QTL-alueita. Numeroidut palkit kuvaavat kromosomi pareja. Kuvassa esitetyt ominaisuudet: $\mathrm{m}=$ maitotuotos, $\mathrm{v}=$ valkuaistuotos, $\mathrm{r}=$ rasvatuotos, $\mathrm{v} \%=$ valkuaispitoisuus, $\mathrm{r} \%=$ rasvapitoisuus, $\mathrm{UT}=$ utaretulehdus, $\mathrm{SCC}=$ somaattinen soluluku.

Hienokartoitus aloitettiin lupaavimmista maidontuotanto-ominaisuuksiin vaikuttavista QTL-alueista. Kartoituksen kautta päädyttiin kahteen kandidaattigeeniin kromosomissa 20. Molemmat geenit liittyvät maitorauhasen kehitykseen sekä laktaatioon. Geeni B:n koodaaman valkuaisaineen tiedetään säätelevän maitorauhasen tiineyden aikaista kehitystä ja maidon eri komponenttien tuotantoa laktaation aikana. Geeni A:lla puolestaan on merkittävä rooli maitorauhasen kehityksessä ennen tiineyttä. Tavoitteena oli löytää kandidaattigeeneistä sekvenssimuuntelua joka selittäisi havaitut vaikutukset tarkastelluissa ominaisuuksissa.

Geenien proteiinia koodaavat sekvenssit selvitettiin ja molemmista geeneistä löydettiin sekvenssimuuntelua. Löydettyjä sekvenssimuutosten yhteyttä maidontuotanto-ominaisuuksien vaihteluun selvitettiin tilastollisin menetelmin suomalaisessa Ayrshire-populaatiossa. Tulosten mukaan molemmat geenit vaikuttavat maidontuotanto-ominaisuuksiin - toinen mahdollisesti veden määrään maidossa ja toinen kokonaistuotokseen. 


\section{Geenitiedon hyödyntäminen jalostusohjelmissa - markkeriavusteinen valinta}

Hienokartoituksen tuloksia (ominaisuuteen kytkeytyvien kromosomialueiden markkereita tai tunnistettuja geenejä) voidaan soveltaa jalostusohjelmissa. Markkereita käyttämällä valinta voidaan kohdistaa suoraan ominaisuuden perinnölliseen osaan ilman häiritseviä ympäristövaikutuksia. Toisaalta markkeriavusteinen valinta nopeuttaa jalostusta siksi, että se voidaan tehdä ominaisuuden ilmenemisestä (sukupuolesta, kehitysvaiheesta ym.) riippumatta. Esimerkiksi sonneja voidaan valita maidontuotanto-ominaisuuksien suhteen jo alkiona, kun normaalisti pitää odottaa sonnien tyttärien tuotostietoja.

MTT:ssä on kehitetty menetelmiä, joilla alkioiden tehokas geneettinen valinta on mahdollista (Virta ym, 2002). Yhdestä eläimestä voidaan tuottaa paljon perimältään valikoituja jälkeläisiä yhdistämällä alkiotuotanto ja alkiodiagnostiikka (kuva 2). Valituilta yksilöiltä huuhdellaan alkioita ja/tai munasoluja. Munasolut kypsytetään ja hedelmöitetään laboratoriossa. Siirtokelpoisiksi kasvatetuista alkioista leikataan näytepala sukupuolen ja valittaviin ominaisuuksiin kytkeytyneiden markkereiden analysointia varten. Geneettisesti määritetyistä alkioista haluttuja ominaisuuksia perineet siirretään vastaanottajiin.



Kuva 2. Alkiodiagnostiikka alkiotuotannossa.

\section{Alkiodiagnostiikka ASMO-ydinkarjassa - tuloksia}

MTT:ssä kehitettyjä alkiodiagnostisia menetelmiä on testattu onnistuneesti ASMO-ydinkarjassa. Vuosina 2002-2003 analysoitiin sukupuolen ja maidontuotantogeenien suhteen yhteensä 145 alkiota, näistä geneettinen määritys onnistui 137 tapauksessa (94\%). Siirrettäväksi valittiin hyvälaatuisia naarasalkioita. Määritetyistä alkioista 55 siirrettiin vastaanottajiin ja näistä 14 johti tiineyteen. Joulukuuhun 2003 mennessä vasikoista 10 oli syntynyt ja ne kaikki olivat naaraita. Vasikoista otettujen kontrollinäytteiden perusteella alkioiden maitogeenimäärityksen onnistuivat $100 \%$ :sti (taulukko 1). 
Taulukko 1. Alkiodiagnostisen menetelmän testaus ASMO-ydinkarjassa. Alkiosta tehdyt määritykset tarkastettiin syntyneistä vasikoista otetuista kontrollinäytteistä. Sekä sukupuolen että maitogeenien määritykset ovat onnistuneet 100\%:sti. Molemmista geeneistä on kaksi vaihtoehtoista muotoa (alleeli 10 ja 20). Yksilöllä, jonka genotyyppi on 1020, on toisessa vastinkromosomissa alleeli 10 ja toisessa alleeli 20 . Homotsygooteilla yksilöillä (1010 ja 2020) on vastinkromosomeissaan identtiset alleelit.

Diagnoosi alkiosta
\begin{tabular}{|r|c|c|c|ll|c|c|c|}
\hline Alkio Nro & Sukupuoli & GeeniA & GeeniB & Syntynyt & Nimi & Sukupuoli & GeeniA & GeeniB \\
\hline 555 & Naaras & 1010 & 1020 & 13.07 .2003 & Suvikki & Naaras & 1010 & 1020 \\
638 & Naaras & 1010 & 1020 & 19.07 .2003 & Suoma & Naaras & 1010 & 1020 \\
639 & Naaras & 1010 & 1020 & 28.07 .2003 & Saima & Naaras & 1010 & 1020 \\
668 & Naaras & 1010 & 1020 & 03.08 .2003 & Seela & Naaras & 1010 & 1020 \\
$885+889$ & Naaras & 1010 & 2020 & 08.11 .2003 & Säihky & Naaras & 1010 & 2020 \\
1101 & Naaras & 1010 & 2020 & 12.11 .2003 & Solja & Naaras & 1010 & 2020 \\
1120 & Naaras & 1020 & 1020 & 19.11 .2003 & Seira & Naaras & 1020 & 1020 \\
1122 & Naaras & 1020 & 1010 & 21.11 .2003 & Suomu & Naaras & 1020 & 1010 \\
1124 & Naaras & 1020 & 2020 & 22.11 .2003 & Saipas & Naaras & 1020 & 2020 \\
1131 & Naaras & 1020 & 2020 & 24.11 .2003 & Susku & Naaras & 1020 & 2020 \\
10015 & Naaras & 1010 & 1010 & & & & & \\
\hline
\end{tabular}

\section{Johtopäätökset}

MTT:ssä on onnistuttu yhdistämään geenikartoituksen tuloksia ja alkioteknologista osaamista. ASMOydinkarjassa oli sukupuolen määrityksen lisäksi mukana kaksi maidontuotantoon vaikuttavaa geeniä. Menetelmä geneettisiä määrityksiä varten on osoittautunut luotettavaksi. Aineisto on kuitenkin vielä pieni ja tavoitteena onkin siirtää ainakin 100 tutkittua alkiota menetelmän luotettavuuden ja alkioiden tiinehdyttävyyden selvittämiseksi.

Tähän mennessä geenikartoituksella tunnistettuja, naudan jalostuksellisesti merkittäviin ominaisuuksiin vaikuttavia geenejä on vähän, mutta tiedon lisääntyessä alkioista voidaan määrittää iso joukko esimerkiksi lehmien terveyteen vaikuttavia perintötekijöitä ja valita sairauksille vastustuskykyisemmät alkiot.

Menetelmää on kehitetty ja kehitetään edelleen. Seuraavana päämääränä on lisätä menetelmään naudan utaretulehdusalttiuteen vaikuttavien kromosomialueiden markkereita. Lisäksi tavoitteena on kehittää alkioiden pakastusmenetelmää niin, että geenimääritetyt alkiot voidaan pakastaa näytteenoton jälkeen odottamaan sopivaa vastaanottajaa.

\section{Kirjallisuus}

Viitala, S., Schulman, N., De Koning, D.-J., Elo, K., Kinos, R., Virta, A., Virta, J., Mäki-Tanila, A. \& Vilkki, J. 2003. Quantitative trait loci affecting milk production traits in Finnish Ayrshire dairy cattle. Journal of dairy science $86,5: 1828-1836$.

Schulman, N.F., Viitala, S.M., De Koning, D.J., Mäki-Tanila, A. \& Vilkki, J.H. 2003. Quantitative trait loci for health traits in Finnish Ayrshire cattle. Journal of dairy science (hyväksytty julkaistavaksi).

Virta, J., Markola, J., Peippo, J., Markkula, M. \& Vilkki, J. 2002. Sex determination of bovine embryo blastomeres by fluorogenic probes. Theriogenology 57, 9: 2229-2236. 